\title{
Studies on the Mode of Action of Antifungal Heptaene Antibiotics
}

\author{
By Y. HENIS AND N. GROSSOWICZ \\ Department of Bacteriology, Hebrew University- \\ Hadassah Medical School, Jerusalem, Israel
}

(Received 28 April 1960)

\begin{abstract}
SUMMARY
The effect of heptamycin (an antifungal heptaene antibiotic closely related to the ascosin-candicidin-trichomycin group) on the respiration of Candida albicans was studied. Heptamycin inhibited the oxidation of pyruvate, lactate and trehalose to a considerable degree. The oxidation of glucose, acetate, acetaldehyde and ethanol was only slightly affected by heptamycin. Anaerobic glycolysis was significantly inhibited. No inhibition of cell-free preparations of trehalase (obtained from C. albicans) or pyruvic carboxylase (from $C$. albicans and Sacharomyces carlsbergensis) was observed; $\mathrm{CO}_{2}$ output by cell-free preparations was not affected either. The uptake of pyruvate and trehalose by $C$. albicans cells is apparently due to an active and inducible mechanism; heptamycin inhibits oxidation of these substances by blocking their penetration into the yeast cell. The oxidation of trehalose in induced organisms was not inhibited by heptamycin whereas that of pyruvate was. Heptamycin, candicidin B, ascosin, trichomycin and amphotericin B inhibited phosphate uptake by non-proliferating suspensions of $C$. albicans. The inhibition was observed at fungistatic concentrations $(0.5-5 \mu \mathrm{g} . / \mathrm{ml}$.) and without any preincubation with the antibiotic. Phosphate uptake by Debaryomyces nicotianae, Pichia farinosa, Cryptococcus albidus and Saccharomyces cerevisiae was similarly affected by heptamycin. Esterification of inorganic phosphate by cell-free extracts of $C$. albicans was not affected by heptamycin. It is suggested that the fungistatic effect of heptaene antibiotics upon sensitive yeasts is mainly due to the prevention of phosphate uptake.
\end{abstract}

\section{INTRODUCTION}

The mode of action of antifungal polyene antibiotics was studied by several workers. Hickey (1953) reported that the activity of ascosin was strongly antagonized by long chain fatty acids and their derivatives. Dimmling (1955) found that trichomycin partially inhibited oxidation of glucose in various Candida strains. According to Aizawa (1956) trichomycin inhibited the induction of mannose and galactose in Candida albicans. Lampen, Morgan \& Slocum (1957) reported that nystatin strongly inhibited both aerobic and anaerobic utilization of glucose by Saccharomyces cerevisiae, C. albicans and Penicillium chrysogenum. Penetration of glucose was not inhibited by the antibiotic. According to Bradley $(1958 a, b)$ inhibition by nystatin was also obtained with cell-free preparations of $C$. stellatoidea. 
In the following experiments, the effects of heptamycin (Henis, Grossowicz \& Aschner, 1957) and other heptaenes upon metabolism of various yeasts is described.

\section{METHODS}

Organisms: Candida albicans strains no. 26 and 27, Debaryomyces nicotianae no. 77, Saccharomyces cervisiae no. 5, S. carlsbergensis no. 7, Cryptococcus albidus no. 59, Pichia fermentans no. 137, obtained from the culture collection of Professor M. Aschner of the Technion, Israel Institute for Technology, Haifa, were used in this study.

Growth medium. For the preparation of cell-free extracts, the yeasts were grown on a rich medium composed of $(\%, w / v)$ : glucose, 2 ; Bacto peptone (Difco), 0.5; Bacto yeast extract (Difco), 0.5; agar, 2 ; the various ingredients were taken up in distilled water; the final $\mathrm{pH}$ was 6:6-6.8.

Chemically defined medium for experiments with intact organisms. The following growth medium was used $(\%, w / v)$ : glucose, $1 ;\left(\mathrm{NH}_{4}\right)_{2} \mathrm{SO}_{4}, 0 \cdot 2 ; \mathrm{K}_{2} \mathrm{HPO}_{4}, 0 \cdot 1$; $\mathrm{MgSO}_{4} .7 \mathrm{H}_{2} \mathrm{O}, \mathbf{0} \cdot 02$; agar, 2 , in distilled water $(\mathrm{pH}, 7 \cdot 0)$. After sterilization of this basal medium for $15 \mathrm{~min}$. at $121^{\circ}$, the following vitamins, sterilized by Seitz filtration, were added (in $\mu \mathrm{g} . / \mathrm{ml}$. final concentration): thiamin, 0.1 ; biotin, 0.01 ; nicotinamide, $0 \cdot 1$; calcium pantothenate, 0.1 ; pyridoxine, $0 \cdot 1$; inositol, 0.5 .

Assay medium was used for determination of antibiotic potency. Its composition $(\%, \mathrm{w} / \mathrm{v})$ was as follows : glucose, 1 ; Bacto peptone (Difco), 0.5; Bacto yeast extract (Difco), 0.5; $\mathrm{NaCl}, 0.5$ in distilled water; $\mathrm{pH} \mathrm{7.2.}$

Starved Candida albicans for measurements of respiration. Because of the high endogenous (aerobic) respiration, C. albicans was subjected to the following starvation procedure: $18 \mathrm{hr}$. organisms grown on the defined medium were washed thoroughly with saline, resuspended in similar medium, but without glucose, and incubated for $8 \mathrm{hr}$. at $30^{\circ}$ with constant shaking. The organisms were then washed again with saline; they could be kept for 3 days, provided they were stored at $2-4^{\circ}$.

Pyruvic acid was determined according to the method of Lu (1939).

Determinations of reducing sugar, calculated as glucose, were made by the method of Somogyi (1945) and Nelson (1944) with the Coleman Junior spectrophotometer and $19 \times 150 \mathrm{~mm}$. test-tubes.

Protein determinations of cell-free extracts were made by the method of Mehl (1945).

Preparations of pyruvic carboxylase and determination of activity. The methods of Green, Herbert \& Subrahmanyan (1941) were followed; the Hughes press (1951) was used to obtain the crude extract. This was purified by precipitation with ammonium sulphate and the fraction precipitated between 42 and $52 \%$ of saturation was collected. The enzymic activity/mg. protein of this fraction was seven to nine times greater than that of the crude extract. Pyruvic oxidase activity was determined manometrically by measuring the $\mathrm{CO}_{2}$ release from pyruvate.

Determinations of phosphate were made by the method of Fiske \& SubbaRow (1925).

Paper chromatography of sugar phosphates was carried out according to Burrows, Grylls \& Harrison (1952) and Hanes \& Isherwood (1949).

Potency of heptaenes. Antibiotic potency was tested with Candida albicans no. 26 and expressed as minimum inhibitory concentration (MIC). The assays (in assay 
medium) were run at $30^{\circ}$ for $24 \mathrm{hr}$, the inoculum being $2 \times 10^{4}$ organisms $/ \mathrm{ml}$. final concentration. The potency assays were made just prior to the experiments described.

Heptamycin, lot no. A 2, MIC $0.5(\mu \mathrm{g} . / \mathrm{ml}$.); Candicidin B (Lechevalier et al. 1953), lot no. 244, Am 25 B, MIC 1.0 and Trichomycin (Hosoya et al. 1952), MIC 0.5 (kindly furnished by Dr H. Lechevalier, Institute of Microbiology, New Brunswick, N.J., U.S.A.); Ascosin (Hickey et al. 1952), lot no. R-16-17, MIC 6.0 (kindly supplied by Dr J. Martin and M. G. Bachman, Commercial Solvents Corp., Terre Haute, Ind., U.S.A.); Amphotericin B (Vandeputte, Wachtel \& Stiller, 1955), MIC 20 (kindly provided by Dr P. Peiser, Squibb Company, Basel, Switzerland).

\section{RESULTS}

Effect of heptamycin on oxygen uptake by Candida albicans. The experiments were carried out by two different methods.

(i) Before measuring the oxygen uptake (in the Warburg apparatus) the organisms $12 \mathrm{mg}$. equiv. dry weight $/ \mathrm{ml}$. were preincubated for $2 \mathrm{hr}$. with $100 \mu \mathrm{g}$. heptamycin/ $\mathrm{ml}$. in phosphate buffered $(\mathrm{m} / 30, \mathrm{pH} 7 \cdot 0)$ saline. The organisms were then washed thoroughly with saline to remove free heptamycin.

(ii) Oxygen uptake was measured without any preincubation, in the presence of heptamycin $(20 \mu \mathrm{g} . / \mathrm{ml}$.) which was added simultaneously with the substrate. The results are summarized in Table 1 and Figs. 1 and 2.

\section{Table 1. Effect of preincubation with heptamycin on the oxidation of various substrates by Candida albicans}

The experiment was carried out in the Warburg apparatus. The reaction mixture contained $0.5 \mathrm{ml}$. of the substrate $(0.15 \mathrm{M}), 1 \mathrm{ml}$. of normal saline, $1 \mathrm{ml}$. phosphate buffer $(0.2 \mathrm{M}, \mathrm{pH} \mathrm{7.2})$ and yeast, $12 \mathrm{mg}$. dry weight equiv. Total volume $3.0 \mathrm{ml}$. In one series, the yeast suspension was preincubated for $2 \mathrm{hr}$. at $30^{\circ}$ with heptamycin $(100 \mu \mathrm{g} . / \mathrm{ml}$. $)$. The antibiotic was removed by centrifugation, and the cells were resuspended in the reaction mixture. The control series was incubated in saline phosphate buffer without heptamycin. Cell suspensions of both series were then transferred to Warburg vessels and oxygen uptake measured as outlined.

The substrate was placed in the side arm and transferred to the main compartment af ter an equilibration period of $15 \mathrm{~min}$. The central well contained a piece of filter paper saturated with $0.2 \mathrm{ml}$. of $15 \%(\mathrm{w} / \mathrm{v}) \mathrm{KOH}$. Gas phase: air; bath temperature: $30^{\circ}$. Oxygen uptake measured for $2 \mathrm{hr}$.

\begin{tabular}{|c|c|c|c|c|}
\hline \multirow[b]{2}{*}{ Substrate } & \multirow{2}{*}{$\begin{array}{c}\text { Preincubation } \\
\text { with } \\
\text { heptamycin }\end{array}$} & \multicolumn{2}{|c|}{$\begin{array}{l}\text { Oxygen uptake } \mu \mathrm{l.} . \mathrm{O}_{2} / \mathrm{hr} . / 12 \mathrm{mg} . \\
\text { yeast }\end{array}$} & \multirow{2}{*}{$\begin{array}{c}\text { Inhibition } \\
(\%)\end{array}$} \\
\hline & & Total & Net & \\
\hline None & $\bar{t}$ & $\begin{array}{l}99 \\
33\end{array}$ & - & $\overline{66 \cdot 7}$ \\
\hline Glucose & $\overline{+}$ & $\begin{array}{l}782 \\
605\end{array}$ & $\begin{array}{l}682 \\
572\end{array}$ & $\overline{16 \cdot 3}$ \\
\hline Lactate & $\overline{+}$ & $\begin{array}{l}350 \\
122\end{array}$ & $\begin{array}{r}251 \\
89\end{array}$ & $\overline{64 \cdot 6}$ \\
\hline Pyruvate & $\overline{+}$ & $\begin{array}{r}466 \\
72\end{array}$ & $\begin{array}{r}367 \\
39\end{array}$ & $\overline{89 \cdot 4}$ \\
\hline Acetate & $\overline{+}$ & $\begin{array}{l}654 \\
518\end{array}$ & $\begin{array}{l}555 \\
485\end{array}$ & $\overline{12 \cdot 7}$ \\
\hline Ethanol & $\overline{+}$ & $\begin{array}{l}719 \\
513\end{array}$ & $\begin{array}{l}620 \\
480\end{array}$ & $\overline{22 \cdot 6}$ \\
\hline Acetaldehyde & $\bar{t}$ & $\begin{array}{l}562 \\
4339\end{array}$ & $\begin{array}{l}463 \\
406\end{array}$ & $\overline{12 \cdot 4}$ \\
\hline
\end{tabular}


Heptamycin inhibited the oxygen uptake with sodium pyruvate as substrate. The inhibition was only slight when pyruvate was replaced by glucose, sodium acetate, acetaldehyde or ethanol. Similar results were obtained whether or not the organisms were preincubated with heptamycin. A lag of about $60 \mathrm{~min}$. was noted in the oxygen uptake with sodium pyruvate as a substrate. However, this lag period was significantly decreased when organisms were preinduced with pyruvate. It may thus be assumed that the lag period was due to a diminished permeability of pyruvate in the uninduced organisms. However, inhibition of oxygen uptake by heptamycin was observed whether or not the organisms were preinduced (Fig. 2).

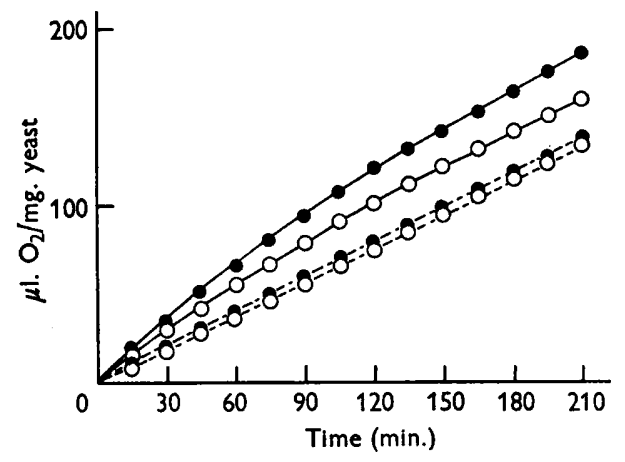

Fig. 1

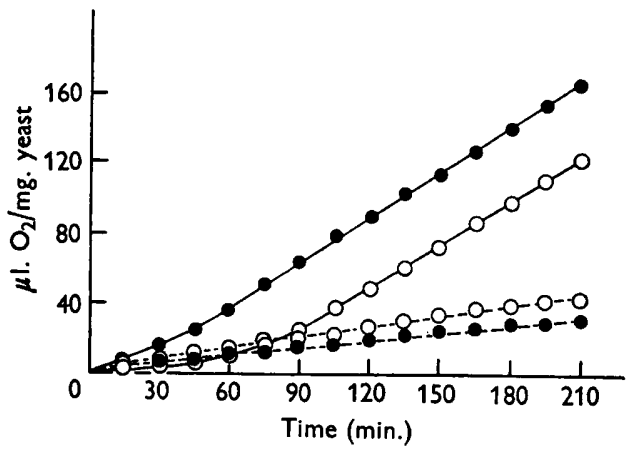

Fig. 2

Fig. 1. Effect of heptamycin on the oxidation of glucose and acetate by Candida albicans. The reaction mixture composition was described (Table 1). Heptamycin (60 $\mu$ g.) was placed in the side arm together with the substrate and introduced to the main compartment of the Warburg vessel after an equilibration period of $15 \mathrm{~min}$. - - glucose;

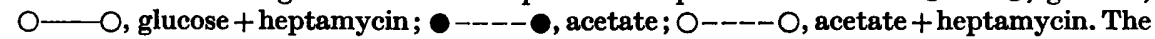
curves represent net oxygen uptake, after endogenous respiration was subtracted.

Fig. 2. Effect of heptamycin on the oxidation of pyruvate by Candida albicans. Organisms both induced and uninduced with pyruvate were used. Induction was carried out by incubating yeast (12 mg. dry weight equiv. $/ \mathrm{ml}$.) with $0.025 \mathrm{M}$-sodium pyruvate and $\mathrm{M} / 15$ phosphate buffer (pH 7.2) for $4 \mathrm{hr}$. The organisms were then washed thoroughly and resuspended in saline. Experimental details as described (Fig. 1). Uninduced organisms: $\bigcirc-O$, pyruvate; ${ }_{-}^{-}-0$, pyruvate + heptamycin. Induced organisms : $0-1$ pyruvate; $\bigcirc---O$, pyruvate + heptamycin.

Pyruvate utilization of Candida albicans in the presence and absence of heptamycin. Experiments were performed in order to ascertain whether or not $C$. albicans is able to utilize pyruvate by a pathway which is not affected by heptamycin. The disappearance of pyruvate from the reaction mixture in the presence and absence of heptamycin was measured. The results are summarized in Fig. 3. It may be seen that in the absence of heptamycin full-rate consumption of pyruvate was obtained after a lag period of $c .1 \mathrm{hr}$.; however, no pyruvate was consumed in the presence of heptamycin. Thus, results comparable to those of oxygen uptake (Fig. 2) were obtained.

Various investigators have shown that pyruvate enters the cell by an active mechanism (Smythe, 1938; Suomalainen \& Oura, 1958). Assuming that such mechanism functions in Candida albicans inhibition of pyruvate consumption by heptamycin may be due to the blocking of the substrate at the surface of the yeast cell, and no effect of heptamycin on pyruvate metabolism in cell-free extracts can 
be anticipated. To test this assumption, cell-free extracts of $C$. albicans and Saccharomyces carlsbergensis were prepared (see Methods), and the activity of the partially purified pyruvic carboxylase was measured in the presence and absence of heptamycin. The results are summarized in Table 2, where it can be seen that the activity of pyruvic carboxylase was only slightly affected by heptamycin.

Effect of heptamycin on anaerobic glycolysis of Candida albicans. An experiment was carried out with cells preincubated with heptamycin and with cells having had no such preincubation. The results, which are summarized in Fig. 4, show that anaerobic glycolysis of $C$. albicans is significantly inhibited by heptamycin. The inhibition becomes pronounced only after a lag period of $\mathbf{3 0} \mathrm{min}$.

\section{Table 2. Activity of pyruvic carboxylase in organisms induced and uninduced with pyruvate, in presence and absence of heptamycin}

The reaction mixture contained sodium pyruvate (NBC, Reagent) $1 \mathrm{~m}$ (adjusted to $\mathrm{pH} \mathrm{6.0} \mathrm{with}$ $\mathrm{NaOH}-0.3 \mathrm{ml}$, citrate- $\mathrm{NaOH}$ buffer $0.5 \mathrm{M}$ pH 6.0-0.3 ml., $100 \mu \mathrm{g}$. heptamycin, and $0.5 \mathrm{mg}$. of enzyme protein (total volume $3.0 \mathrm{ml}$.). The reaction mixture (without pyruvate) was incubated for $30 \mathrm{~min}$. at $30^{\circ}$ in the Warburg vessel after which time pyruvate was added (via the side arm) and $\mathrm{CO}_{2}$ output determined for $20 \mathrm{~min}$. In the absence of either the enzyme or substrate no $\mathrm{CO}_{2}$ output was obtained even without the antibiotic.

Induction with pyruvate was carried out by suspending $24 \mathrm{hr}$. organisms $(12 \mathrm{mg}$. dry weight equiv. $/ \mathrm{ml}$.) in the chemically defined medium with $0.025 \mathrm{M}$-sodium pyrıvate (instead of glucose). After $6 \mathrm{hr}$. of incubation with shaking at $30^{\circ}$ the organisms were washed with saline and pyruvic carboxylase extracted as described (see Methods).

\begin{tabular}{|c|c|c|c|c|}
\hline Enzyme source & $\begin{array}{c}\text { Induction } \\
\text { with } \\
\text { pyruvate }\end{array}$ & Heptamycin & $\begin{array}{l}\mu \mathrm{l} . \mathrm{CO}_{2} / \mathrm{mg} . \\
\text { protein in } \\
10 \mathrm{~min} .\end{array}$ & $\begin{array}{c}\text { Inhibition } \\
(\%)\end{array}$ \\
\hline Saccharomyces carlsbergensis & - & $\bar{t}$ & $\begin{array}{l}570 \\
530\end{array}$ & $\overline{7 \cdot 1}$ \\
\hline Candida albicans no. 26 & - & $\overline{+}$ & $\begin{array}{l}238 \\
224\end{array}$ & $\overline{5.9}$ \\
\hline C. albicans no. 26 & $\begin{array}{l}+ \\
+\end{array}$ & $\bar{t}$ & $\begin{array}{l}258 \\
241\end{array}$ & $\overline{6 \cdot 6}$ \\
\hline
\end{tabular}

Effect of heptamycin on the oxidation of trehalose. Candida albicans strain no. 27, utilized trehalose after induction. The effect of heptamycin upon oxygen uptake with trehalose as substrate was tested on organisms preinduced and uninduced with trehalose; the results summarized in Fig. 5 show that heptamycin strongly inhibited the oxygen uptake of uninduced organisms. No inhibition of oxygen uptake by heptamycin was observed during the first $90 \mathrm{~min}$. using trehalose-induced cells; upon more prolonged incubation, however, oxygen uptake was slightly decreased.

Effect of heptamycin on trehalase activity in cell-free extracts. Candida albicans, strain no. 27, grown on yeast extract + glucose agar was harvested after $24 \mathrm{hr}$. incubation, washed thoroughly with saline, and induction with trehalose carried out as described above (measured by increased oxygen uptake) (Fig. 5). Cell-free extracts were prepared with the Hughes Press from induced and uninduced organisms. Similar trehalase specific activities were noted in both preparations. In addition, the effect of heptamycin on trehalase activity was examined. Preincubation of cell-free extracts with heptamycin did not affect trehalase activity (see Table 3). 


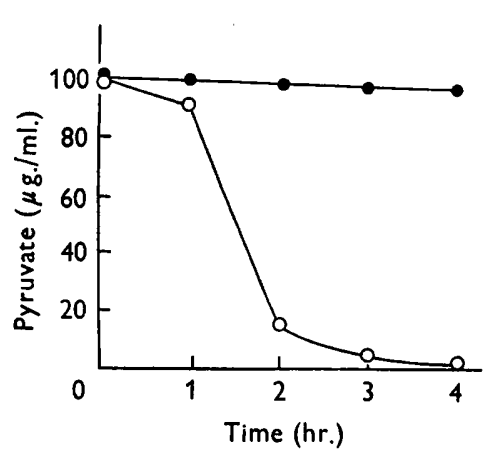

Fig. 3

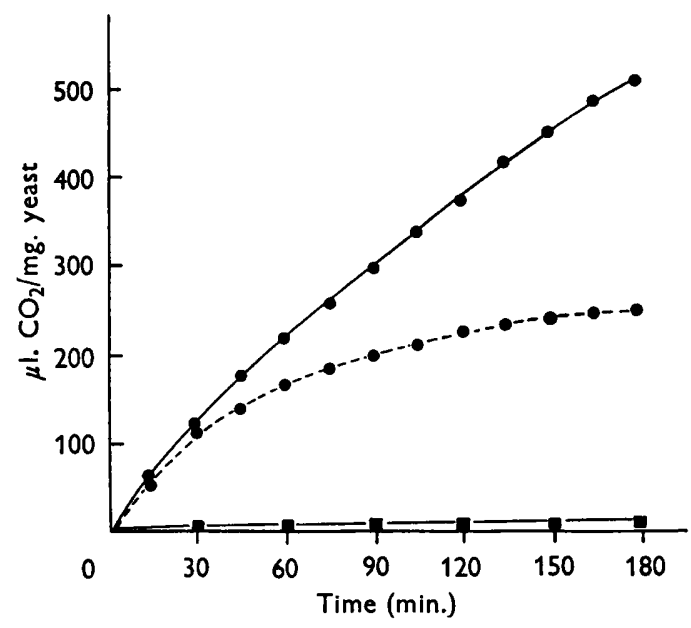

Fig. 4

Fig. 3. Effect of heptamycin on pyruvate utilization by Candida albicans. The reaction mixture contained $15 \mathrm{mg}$. (dry weight equiv.) C. albicans strain $26,1 \mathrm{ml} .0 \cdot 2 \mathrm{M}$-phosphate buffer $\mathrm{pH} 7 \cdot 2,300 \mu \mathrm{g}$. sodium pyruvate (Reagent, NBC), and $60 \mu \mathrm{g}$. heptamycin in a total volume of $3 \mathrm{ml}$. It was incubated $4 \mathrm{hr}$. in $\mathrm{a} 30^{\circ}$ water bath and samples taken at intervals. The organisms were removed by centrifugation and the remaining pyruvate in the supernatant determined.

O, pyruvate;

, pyruvate + heptamycin.

Fig. 4. Anaerobic glycolysis of Candida albicans in the presence and absence of heptamycin. Organisms not preincubated with the antibiotic were used, and $60 \mu \mathrm{g}$. heptamycin were added to the reaction mixture at zero time. The reaction mixture contained $0.5 \mathrm{ml}$. of $0.15 \mathrm{M}$-glucose, $1.0 \mathrm{ml}$. of $0.1 \mathrm{M}-\mathrm{KH}_{2} \mathrm{PO}_{4}$ and $12.5 \mathrm{mg}$. yeast (dry weight equiv.). Final volume $-3 \mathrm{ml}$. The substrate was placed in the side arm of the Warburg vessel and was transferred to the main compartment after equilibration for $15 \mathrm{~min}$. Gas phasenitrogen. Temperature $-30^{\circ}$. -0 , without heptamycin; $0-. .-$, with heptamycin; $\square$, endogenous glycolysis, with and without the antibiotic.

\section{Table 3. Trehalase activity in the presence and absence of heptamycin}

The enzyme was prepared from Candidaalbicans strain 27 ; the reaction mixture contained $10 \mathrm{mg}$. trehalose, $0.5 \mathrm{ml}$. phosphate buffer (pH 5.8), $40 \mu \mathrm{g}$. heptamycin, and $0.5 \mathrm{ml}$. (15 mg. protein) of the enzyme preparation (total volume $2.0 \mathrm{ml}$.). The reaction mixture was incubated for $4 \mathrm{hr}$. in $30^{\circ}$ water bath. Aliquots of $1.0 \mathrm{ml}$. were taken and the protein precipitated by the addition of $1 \mathrm{ml}$. of $5 \%(\mathrm{w} / \mathrm{v}) \mathrm{ZnSO}_{4}$ and $1.0 \mathrm{ml}$. equimolar solution of $\mathrm{Ba}(\mathrm{OH})_{2}$. After centrifugation the reducing sugar in the supernatant was determined. The reaction mixture without enzyme and heptamycin was used as a blank.

Preinduction of cells with trehalose prior to enzyme extraction*

$$
\begin{gathered}
\text { Trehalose in } \\
\text { the reaction } \\
\text { mixture }
\end{gathered}
$$

+
+
+

$$
\begin{gathered}
\text { Incubation with } \\
\text { with } \\
\text { heptamycin }
\end{gathered}
$$$$
\begin{aligned}
& - \\
& \overline{+} \\
& +
\end{aligned}
$$

$\mu$ g. glucose/mg. protein

11

* For details of induction experiment see Fig. 5. 
Effect of heptamycin and other heptaene antibiotics on phosphate uptake by Candida albicans. Heptamycin in fungistatic concentrations $(5 \mu \mathrm{g} . / \mathrm{ml}$.) produced immediate and complete inhibition of phosphate uptake by $C$. albicans (see Fig. 6). The other heptaenes also brought about complete inhibition of phosphate uptake at minimum inhibiting concentrations (Fig. 7). Heptamycin at $0 \cdot 15 \mu \mathrm{g} . / \mathrm{ml}$. which only partially inhibited growth, showed a $50 \%$ inhibition of phosphate uptake.

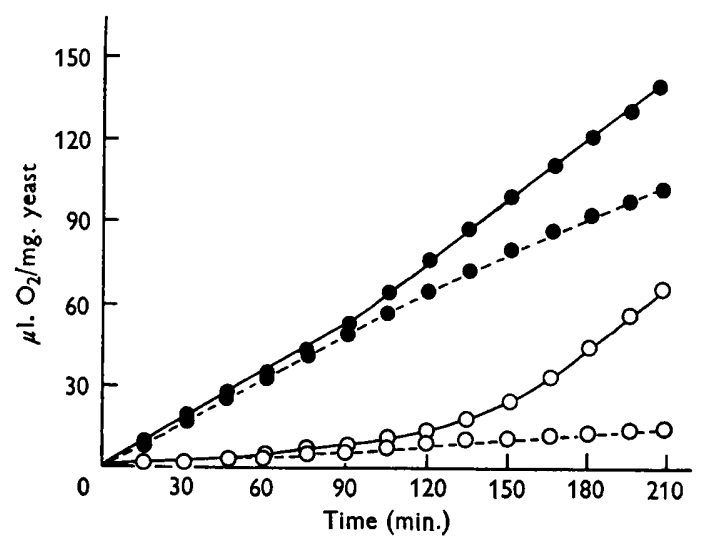

Fig. 5

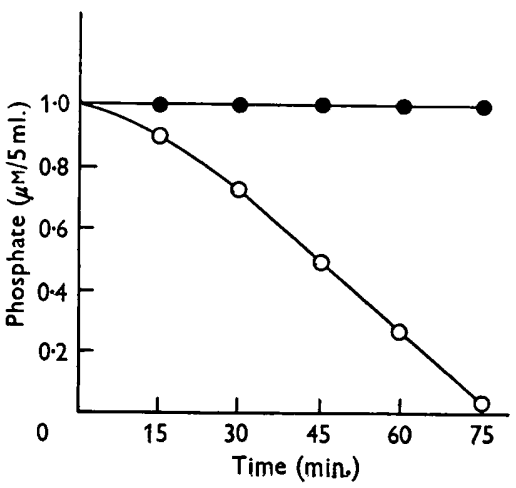

Fig. 6

Fig. 5. Effect of heptamycin on trehalose oxidation by Candida albicans strain 27. Induction with trehalose $(0.025 \mathrm{~m})$ was carried out by incubating the organisms $(4 \mathrm{mg}$. dry weight equiv./ml.) in the chemically defined medium (without glucose) for $4 \mathrm{hr}$. at $30^{\circ}$. The organisms were then washed thoroughly and resuspended in a reaction mixture which contained $0.025 \mathrm{M}$-trehalose, and $60 \mu \mathrm{g}$. heptamycin in a total volume of $3 \mathrm{ml}$. The trehalose and the antibiotic were placed in the side arm and transferred to the main compartment of the Warburg vessels after an equilibration period of $15 \mathrm{~min}$. Uninduced organisms: $\bigcirc-O$, trehalose; $\mathrm{O}---\mathrm{O}$, trehalose + heptamycin. Induced organisms: - - trehalose; trehalose + heptamycin.

Fig. 6. Effect of heptamycin on phosphate uptake by Candida albicans. To the chemically defined medium containing inorganic phosphate $(0 \cdot 2 \mu \mathrm{M} / \mathrm{ml}$.) thoroughly washed C.albicans organisms were added $(18 \mathrm{hr}$. culture) to give a final concentration of $1.0 \mathrm{mg} . / \mathrm{ml}$. (dry weight equiv.); $100 \mathrm{ml}$. aliquots with and without heptamycin (5.0 $\mu \mathrm{g} . / \mathrm{ml}$.) were transferred to $250 \mathrm{ml}$. Erlenmeyer flasks and incubated at $30^{\circ}$ for $75 \mathrm{~min}$. in a Ross-Kershaw shaker. Ten ml. samples were taken at intervals, cooled immediately in ice, and the organisms removed by centrifugation; $5 \mathrm{ml}$. aliquots were used to determine the remaining inorganic phosphate. $\mathrm{O}-\mathrm{O}$, without heptamycin;

Effect of heptamycin on phosphate uptake by various yeasts. Assuming that the primary action of heptaene antibiotics was the inhibition of inorganic phosphate uptake one would expect a correlation between the degree of inhibition of phosphate uptake and the sensitivity of the various yeasts to these agents. Sensitive and resistant yeasts were examined to test this hypothesis. The same method as described above was used. The results are summarized in Table 4. A direct relation may be seen between the sensitivity of a given yeast strain to heptamycin and the minimal concentration of the antibiotic required to completely inhibit phosphate uptake. Inhibition of phosphate uptake by Debaryomyces nicotianae, a relatively resistant strain, was observed only at antibiotic concentrations great enough to show a fungistatic effect. A similar effect was observed with yeasts which were highly sensitive to heptamycin. 
Effect of heptamycin on $\mathrm{CO}_{2}$ output from glucose and esterification of inorganic phosphate by cell-free extracts of Candida albicans. The inhibition exhibited by heptamycin on anaerobic glycolysis and phosphate uptake in intact organisms may be due to the action of the antibiotic either within the cell or at its surface. Liberation of $\mathrm{CO}_{2}$ from glucose and formation of organic phosphates were examined using cell-free extracts of $C$. albicans in the presence and absence of heptamycin. Figure 8 shows that heptamycin did not affect the formation of $\mathrm{CO}_{2}$ by cell-free extracts to any significant degree. The incorporation of inorganic phosphate into sugar phosphates by cell-free extracts was also tested. Samples of the reaction mixture were

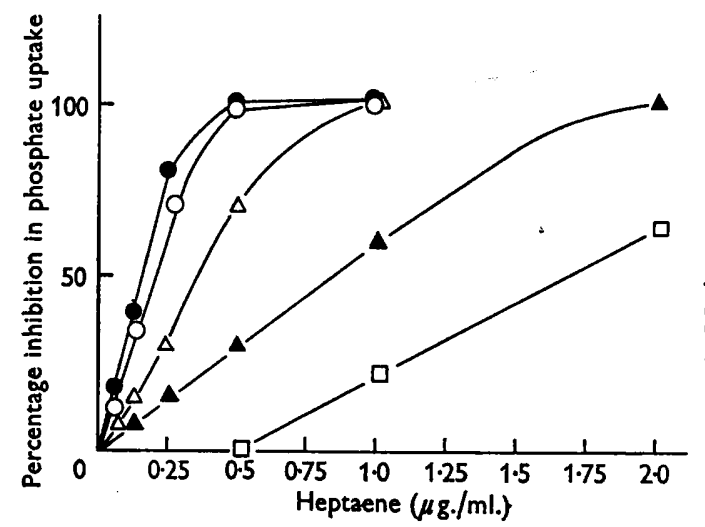

Fig. 7

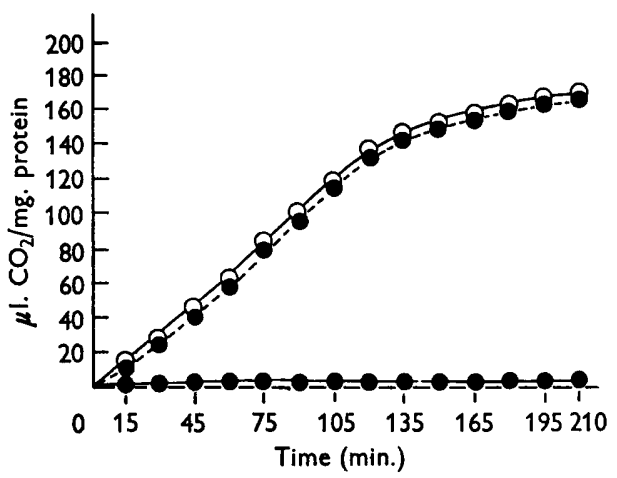

Fig. 8

Fig. 7. Inhibition of phosphate uptake by various heptaenes. Test tubes $(16 \times 190 \mathrm{~mm}$.), each containing $5 \mathrm{ml}$. of the chemically defined medium, $0 \cdot 2 \mu \mathrm{M} / \mathrm{ml}$. inorganic phosphate, $3 \mathrm{mg}$. dry weight equiv. Candida albicans and the antibiotic indicated were incubated for $90 \mathrm{~min}$. at $30^{\circ}$ with continuous shaking. The reaction was stopped by immediately cooling the tubes in ice. The cells were removed by centrifugation and the inorganic phosphate in the supernatant fluid was estimated. Simultaneously the minimum inhibitory concentration of the various heptaenes for $C$. albicans was determined. Heptamycin 0.5 $\mu \mathrm{g} . / \mathrm{ml}$. MIC, see Methods for potency of heptaenes. $\bigcirc-\bigcirc$, trichomycin $0.5 \mu \mathrm{g} . / \mathrm{ml}$. MIC; $\triangle \longrightarrow \Delta$, candicidin B $1.0 \mu \mathrm{g} . / \mathrm{ml}$. MIC; $\Delta-\triangle$, amphotericin $B$ $2 \cdot 0 \mu \mathrm{g} . / \mathrm{ml}$. MIC; $\square \longrightarrow \square$, ascosin 6.0 $\mu \mathrm{g}$. $/ \mathrm{ml}$. MIC.

Fig. 8. Effect of heptamycin on $\mathrm{CO}_{2}$ output from glucose by Candida albicans cell-free extract. The reaction mixture contained glucose $150 \mu \mathrm{M}$, phosphate buffer $150 \mu \mathrm{M}$ (pH 5.8), heptamycin $60 \mu \mathrm{g}$, and cell-free extract (20 mg. protein). Total volume $3.0 \mathrm{ml}$. The glucose and the antibiotic were put in the side arm of the Warburg vessel and introduced to the main compartment after an equilibrium period of $15 \mathrm{~min}$. Gas phase : air; temperature $30^{\circ}$. $\mathrm{O}_{-} \mathrm{O}$, without heptamycin; ----0 , with heptamycin; $-\longrightarrow$ glucose absent, with and without the antibiotic.

examined for inorganic phosphate at the beginning and at the end of the experiment, and tests for the detection of sugar phosphates were carried out simultaneously by paper chromatography. Most of the sugar phosphate appeared as hexose diphosphate. No difference was observed in the amounts of esterified phosphates found in the presence or absence of heptamycin (Table 5).

\section{DISCUSSION}

Heptamycin was found to greatly inhibit the oxygen uptake by Candida albicans when pyruvate or lactate was used as substrate, whereas only a slight effect was noted when the substrate was glucose, acetate, acetaldehyde or ethanol. It would 
seem that the effect of the antibiotic was due to the blocking of the active transport of pyruvate and lactate into the yeast cell, rather than to interference with metabolism inside the cell. This hypothesis is supported by the fact that the cell-free pyruvic carboxylase was not affected by heptamycin. The same explanation holds for the inhibition by heptamycin of oxygen uptake with trehalose as substrate, as trehalase activity was not affected by the antibiotic. Thus, the effect of heptamycin can be traced to its action at the cell surface. However, our experiments do not exclude the possibility that heptamycin may also inhibit the intracellular oxidative metabolism of pyruvate.

Cell-free extracts of yeast uninduced with pyruvate or trehalose contained pyruvic carboxylase and trehalase activities in amounts equal to those found in

Table 4. Comparison of the concentration of heptamycin required to inhibit growth and block phosphate uptake. The experiment was carried out as described in Fig. 7

$\begin{array}{lcc}\text { Growth } & \begin{array}{c}\text { Phosphate } \\ \text { uptake } \\ \text { Strain }\end{array} & \begin{array}{c}\text { Minimum concentration of } \\ \text { heptamycin inhibiting }\end{array} \\ \text { Candida albicans } 26 & \mu \mathrm{g} . / \mathrm{ml} .) & 0.5 \\ \text { Saccharomyces cerevisiae } & 0.5 & 0.25 \\ \text { Cryptococcus albidus } & \mathbf{0 . 0 6} & \mathbf{0 . 2 5} \\ \text { Debaryomyces nicotianae } & \mathbf{0 . 2 5} & \mathbf{6 5}\end{array}$

Table 5. Effect of heptamycin on esterification of inorganic phosphate by cell-free extracts of Candida albicans

\begin{tabular}{|c|c|c|c|c|}
\hline \multirow[b]{2}{*}{ Substrate } & \multirow[b]{2}{*}{ Heptamycin } & \multicolumn{2}{|c|}{$\begin{array}{c}\mu \mathrm{M} \text { inorganic phosphate (in the } \\
\text { reaction mixture) }\end{array}$} & \multirow{2}{*}{$\begin{array}{c}\text { Phosphate } \\
\text { esterified } \\
(\mu \mathrm{M})\end{array}$} \\
\hline & & $0 \mathrm{~min}$. & 210 min. & \\
\hline None & - & 150 & 143 & - \\
\hline Glucose & - & 150 & 70 & 73 \\
\hline $\begin{array}{l}\text { None } \\
\text { Glucose }\end{array}$ & + & $\begin{array}{l}150 \\
150\end{array}$ & $\begin{array}{r}143 \\
71\end{array}$ & $\overrightarrow{72}$ \\
\hline
\end{tabular}

For experimental conditions see Fig. 8.

induced organisms. However, the oxidation of these substrates by intact uninduced organisms was preceded by a lag period, indicating that transport of these substrates into the cell is inducible. The effect of heptamycin may be caused by inhibition of the synthesis of the inducible permeases of pyruvate and trehalose (Cohen \& Monod, 1957). On the other hand, heptamycin prevented the uptake of pyruvate but not trehalose by either uninduced or induced organisms. This difference can be explained by assuming that heptamycin inactivated the pyruvate permease of Candida albicans, but not the trehalose permease.

Fungistatic concentrations of heptamycin and other heptaenes caused an immediate and complete inhibition of phosphate uptake by various yeasts. Similar observations were made by Bradley (1958b) and by Osteux,Tran-Van-Ky \& Biguet (1958). On the other hand, even high concentrations of heptamycin had no effect on esterification of inorganic phosphate in cell-free extracts of Candida albicans. It may thus be assumed that inhibition of phosphate uptake in intact organisms is due 
to interference by the heptaenes with the mechanism of phosphate transport into the cell. Goodman \& Rothstein (1957) and Mitchell (1957), have shown that yeast and bacteria are equipped with mechanisms for the active uptake of inorganic phosphate presumably located at the cell membrane. The lipophilic properties of the heptaenes may explain their possible affinity for the lipoproteins of the cell membrane (Mitchell, 1957).

The effect of heptamycin may not be limited to the external cell membrane but may affect intracellular structures (e.g. mitochondria) as well. If this were so, phosphate would not only be prevented from entering the cell but also its flow through the cell compartments would be distorted (Lynen, Hartmann, Netter \& Schuegraf, 1959). It is possible that the remarkable differences in effect of heptamycin on aerobic and anaerobic metabolism of glucose (Figs. 1, 4) are due to such a disturbance. Alternatively, the uptake of glucose by the cell may be different under aerobic and anaerobic conditions. However, according to Lynen et al. (1959) oxygen did not influence the permeability of glucose into baker's yeast.

The results described above differ from those obtained with the tetraene antibiotic, nystatin (Lampen et al. 1957; Bradley, 1958 a, $b$ ). Thus, Lampen et al. (1957) found that nystatin (and amphotericin A, B) inhibited both aerobic and anaerobic utilization of glucose, the latter process (glycolysis) was somewhat more sensitive. Bradley (1958a) found nystatin to inhibit glucose utilization not only in intact Candida stellatoidea but in acetone treated organisms and cell-free extracts as well. We, on the other hand, found the oxidation of glucose to be only slightly affected by heptamycin. The possibility that nystatin binds inorganic phosphate (Bradley, $1958 b$ ) does not hold for heptamycin, as the uptake of inorganic phosphate in the present experiments was almost completely blocked even when the ratio of phosphate to heptamycin (w/w) was increased to 200:1 in the reaction mixture. Furthermore, as inorganic phosphate is essential to organisms both sensitive and resistant to heptamycin, no selective action of heptamycin on various yeasts was to be expected. Therefore, the mode of action of the heptaene antibiotics tested seems to differ in some respects from that of nystatin.

The authors are greatly indebted to Professor M. Aschner (Technion, Israel Institute for Technology, Haifa), for his advice and encouragement. They are also indebted to Dr H. Lechevalier, Institute of Microbiology, New Brunswick, N.J., U.S.A., for candicidin B and trichomycin, to Dr J. Martin and M. G. Bachman, Commercial Solvents Corporation, Terre Haute, Ind., U.S.A., for the sample of ascosin and to Dr P. Peiser, of Squibb Company, Basel, Switzerland, for amphotericin B.

This paper forms part of a Ph.D. thesis submitted by Y. Henis to the Senate of the Hebrew University, Jerusalem, Israel.

\section{REFERENCES}

Arzawa, H. (1956). The influence of various antibiotics and antifungal drugs upon adaptive enzyme formation of Candida albicans. Chemotherapy (Japan), 3, 260.

Bradley, S. G. $(1958 a)$. Effect of nystatin on Candida stellatoidea. Antibiot. \& Chemother. 8, 282.

BradLey, S. G. $(\mathbf{1 9 5 8} b)$. Interactions between phosphate and nystatin in Candida stellatoidea. Proc. Soc. exp. Biol., N.Y. 98, 786. 
Burrows, S., Grylls, E. S. M., \& Harrison, J. S. (1952). Paper chromatography of phosphoric esters. Nature, Lond. 170, 800.

Cohen, G. N. \& Monod, J. (1957). Bacterial permeases. Bact. Rev. 21, 169.

Dimmling, Th. (1955). In vitro Untersuchungen über die Aktivitaet von Trichomycin gegen Hefen und hefeaenliche Pilze. Z $b l$. Bakt. (Abt. 1), 163, 530.

Fiske, C. H. \& SubbaRow, Y. (1925). The colorimetric determination of phosphorus. J. biol. Chem. 66, 375.

Goodman, J. \& Rothstein, A. (1957). The active transport of phosphate into the yeast cell. J. gen. Physiol. 40, 915.

Green, D. E., Herbert, D. \& Subrahmanyan, V. (1941). Carboxylase. J. biol. Chem. 138, 327.

HANes, C. S. \& Isherwood, F. A. (1949). Separation of the phosphoric esters on the filter paper chromatogram. Nature, Lond. 164, 1107.

Henis, Y., Grossowicz, N. \& Aschner, M. (1957). Heptamycin, an antifungal and antiprotozoal antibiotic. Bull. Res. Counc. Israel, 6 E, VII.

Hickey, R. J. (1953). The antagonism between the antifungal antibiotic, ascosin, and some long-chain, unsaturated acids. Arch. Biochem. Biophys. 46, 331.

Hickey, R. J., Corum, C. S., Hidy, P. H., Cohen, J. R., Nager, U. F. B. \& Cropper, E. (1952). Ascosin, antifungal antibiotic produced by a streptomycete. Antibiot. \& Chemother. 2, 472.

Hosoya, S., Kematu, N., Soeda, M., Yamaguti, T. \& Sonoda, Y. (1952). Studies on trichomycin, which has activities against trichomonas and candida. J. Antibiotics (Japan), 5, 564.

Hugres, D. E. (1951). Press for disrupting bacteria and other microorganisms. Brit. J. exp. Path. 32, 97.

Lampen, J. O., Morgan, E. K. \& Slocum, A. C. (1957). The effect of nystatin on the utilization of substances by yeast and other fungi. J. Bact. 74, 297 .

Lechevalrer, H., Acker, R. F., Conke, C. T., Henseler, C. M. \& Waksman, S. A. (1953). Candicidin, a new antifungal antibiotic. Mycologia, 65, 55.

Lu, G. D. (1939). Studies on metabolism of pyruvic acid in normal and vitamin $B_{1}-$ deficient state: rapid specific and sensitive method for estimation of blood pyruvate. Biochem. J. 33, 249.

Lynen, F., Hartmann, G., Netter, K. F. \& Schuegraf, A. (1959). In Ciba Foundation Symposium on The regulation of cell metabolism, Ed. by G. E. W. Wolstenholme \& C. M. O'Connor, p. 261.

MenL, J. W. (1945). The biuret reaction of proteins in the presence of ethylene glycol. J. biol. Chem. 157, 173.

Mitchell, P. (1957). Theory of membrane transport from studies of bacteria. Nature, Lond. 180, 134.

Nelson, N. (1944). A photometric adaptation of Somogyi method for the determination of glucose. J. biol. Chem. 153, 375.

Osteux, R., Tran-VAN-Ky \& Biguet, J. (1958). Contribution à l'étude du mode d'action de la nystatine sur Candida albicans. C.R. Acad. Sci. Paris, 247, 2475.

Smythe, C. V. (1938). The utilization of pyruvic acid by bakers' yeast. J. biol. Chem. 125, 635.

Soмоgyi, M. (1945). A new reagent for the determination of sugars. J. biol. Chem. 160, 61 .

Suomalainen, H. \& Oura, E. (1958). Cell permeability and decarboxylation of $\alpha$-keto acids and intact yeasts. Biochim. biophys. Acta, 28, 120.

Vandeputte, H., Wachtel, J. L. \& Stiller, E. (1955). Amphotericins A and B, antifungal antibiotics produced by a streptomycete. II. The isolation and properties of the crystalline amphotericins. p. 587. In Antibiotics Annual, 1955/56. Ed. H. Welch \& F. Marti-Ibanez, New York: Med. Encyclopedia Inc. 